\title{
Isolation of Phosphate Solibulizing Actinomycetes from Forest Soils of Mahabubnagar District
}

\author{
G. Balakrishna, A. Shiva Shanker and Pavan Kumar Pindi \\ Department of microbiology, Palamuru University \\ Mahabubnagar-509001 A.P., India
}

\begin{abstract}
The present study was carried out in order to establish a suitable protocol for the screening of phosphate solubilizing actinomycetes. 10 isolates with distinct morphology were isolated and purified on starch casein agar from forest soils of Mahabubnagar district, Andhra Pradesh. These isolates screened for phosphate solubilizing activity on modified starch casein agar which contains tricalcium phosphate as a sole ' $\mathrm{P}$ ' source. Out of 10 isolates, 4 isolates were showed the activity of phosphate solubilization. Among them two isolates were showed good activity. The solubilizing activity was maximum at $\mathrm{pH}$ 7.0 and with incubation period of 10 days. The isolate PSA-7, which is showing maximum activity of phosphate solubilization selected for 16S rRNA partial gene sequence and BLAST analysis revealed that the strain shown 98\% similarity with streptomyces spp. The present study indicates that actinomycetes play an important role in the phosphate solubilization there by increases the soluble phosphate concentration, which is an essential for plant growth.
\end{abstract}

Keywords: Actinomycetes, 16S r RNA, Phosphate Solubilization, Starch Casein Agar

\section{Introduction}

Phosphorus is the second most important plant nutrient after nitrogen [1]. The most important function of phosphate in the plant system is energy storage. It exists in nature as a variety of insoluble organic and inorganic forms. Phosphate availability in soil is low because of it's fixation as insoluble phosphates of Calcium, Aluminum and Iron. Since deficiency of ' $\mathrm{P}$ ' restrict the plant growth, to obtain optimum yields chemical phosphate fertilizers are widely used [2]. 'P' supply through biological means is a viable alternative, phosphate solubulizing bacteria, phosphate solubulizing fungi and actinomycetes are the potential candidates for dissolving the organic and inorganic phosphate compounds [3].

\subsection{Phosphate solubilizers:}

Microbes which solubilize the bound phosphate and rock phosphate into simple are called phosphate solubilizer [4]. They secret organic acids such as formic acid, lactic acid, succinic acid, propionic acid and hydroxyl acid to solubilize the bound phosphate in the soil. Till now, the information on the phosphate solubilizing actinomycetes is scanty. Therefore the present investigation was designed to study the phosphate solubilizing actinomycetes.

Actionomycetes are prokaryotic, spore forming, gram positive bacteria. Their filamentous nature, branching pattern and conidia formation are similar to fungi, for this reason they are known as "ray fungi". The spore size, spore characters, prokaryotic nuclei and are susceptible to anti bacterial antibiotics which are similar to bacterial characteristics. For this reason they are known as filamentous bacteria.

\section{Materials and Methods}

\subsection{Soil sample collection}

Soil samples $(500 \mathrm{~g})$ were collected from rhizosphere region of plants in Nallamala forest of Mahabubnagar district of Andhra Pradesh, (Lat $16^{0} 22^{1} 35^{11} \mathrm{~N}, 78^{0} 45^{1} 21^{11} \mathrm{E}$ ). The samples were taken up to a depth of $15 \mathrm{~cm}$, after removing approximately $3 \mathrm{~cm}$ of the soil surfaces. The soil samples were placed in a sterile poly ethylene bags, closed tightly to avoid external contamination and transported to the laboratory and maintained at $4^{0} \mathrm{C}$ until further use.

\subsection{Isolation of Actinomycetes:}

Starch casein agar (SCA) medium (g/l: starch 10; casein 0.3; $\mathrm{KNO}_{3} 2 ; \mathrm{NaCl} 2 ; \mathrm{K}_{2} \mathrm{HPO}_{4} 2 ; \mathrm{MgSO}_{4} 7 \mathrm{H}_{2} \mathrm{O} 0.05 ; \mathrm{CaCO}_{3} 0.02$; $\mathrm{FeSO}_{4} 7 \mathrm{H}_{2} \mathrm{O} 0.01$ Agar 18; $\mathrm{p}^{\mathrm{H}}$ 7.2) employed for the isolation of actinobacteria. Culture medium was prepared and sterilized at $121^{\circ} \mathrm{C}$ in $15 \mathrm{lbs}$ pressure for $15 \mathrm{~min}$ and supplemented with tetracycline $(100 \mu \mathrm{g} / \mathrm{ml})$ and Amphotericin B $(50 \mu \mathrm{g} / \mathrm{ml})$ to prevent bacterial growth and fungal growth respectively $[5,6]$. 
The collected soil samples (1gr) were serially diluted in distilled water up to $10^{-6}$ dilution, and $0.1 \mathrm{ml}$ of the diluted samples were spread over the starch casein agar plates. The plates were incubated at $30^{\circ} \mathrm{C}$ for 7-10 days. After incubation the actinomycetes colonies were observed. Pure cultures were obtained from selected colonies by repeated sub culturing on starch casein agar slants.

\section{Characterization of Actinomycetes}

The selected actinomycetes were characterized by morphological and biochemical tests [7]. Morphological tests consist of macroscopic and microscopic methods. The mycelium structure, color arrangement of spores on the mycelium and colors of colonies were observed and compared with Bergey's manual of determinative bacteriology. Moreover, several biochemical tests such as IMVIC tests, catalase, urease, lipase and starch hydrolysis, were determined.

\section{Screening of phosphate solubilizing actinomycetes}

Actinomycetes cultures were inoculated on modified starch casein agar medium containing $2 \%$ of tricalcium phosphate as a sole phosphorous source for selectively screening the actinomycetes, which have the ability to release inorganic phosphate from tricalcium phosphate. The inoculated plates were incubated at $30^{\circ} \mathrm{C}$ for $7-10$ days [8]. After the completion of the incubation period, the plates were observed for the presence of clear zone around the colonies which indicates the extent of phosphate solubilization.

\section{Effect of pH and incubation period on phosphate solubilization}

The strains which showed the maximum clear zone in the plates were further tested for optimum phosphate solubilization at different $\mathrm{p}^{\mathrm{H}}$ and incubation periods.

\subsection{Effect of pH}

Different $\mathrm{pH}$ concentrations viz ., 6.0, 6.5, 7.0, 7.5and 8.0 of the modified starch casein agar plates were prepared using buffer solution and inoculated with the cultures and incubated at $30^{\circ} \mathrm{C}$ for 7 days

\subsection{Effect of incubation period}

Single colony was inoculated on modified starch casein agar plates and incubated at different incubation periods $\left(3^{\text {rd }}\right.$ day- $20^{\text {th }}$ day) to study the effect on phosphate solubulization by keeping $\mathrm{p}^{\mathrm{H}}$ at 7.2 and temperature at $30^{\circ} \mathrm{C}$.

\section{Molecular characterization}

Among the 10 isolates, 4 isolates showed phosphate solubilization activity (Table-1).Among them two isolates were very potential. These two strains showed larger zones of clearance indicating an efficient solubilization of phosphate than other strains, on plate assay. In order to identify the strain PSA-7 which showed maximum phosphate solubilization, several molecular and bioinformatical assays were performed.

\subsection{Genomic DNA isolation}

Genomic DNA isolation was conducted according to the protocol described by Corbin method with some modifications. Briefly, a single colony was cultured in $50 \mathrm{ml}$ liquid ISP2 medium for $24 \mathrm{~h}$ in shaker incubator at $26^{\circ} \mathrm{C}$. Then the culture was centrifuged for $3 \mathrm{~min}$ at $5000 \mathrm{rpm}$ and supernatant was discarded. The bacterial cells were pulverized in liquid nitrogen, suspended in a solution-I, containing $10 \mathrm{mM}$ Tris (pH: 7.4), $1 \mathrm{mM}$ EDTA, 0.5\% SDS and $0.1 \mathrm{mg} / \mathrm{ml}$ of Proteinase K, and lysed by incubation at $37^{\circ} \mathrm{C}$ for $1 \mathrm{~h}$, then the solution -II containing $0.8 \mathrm{NaCl}$ and $1 \% \mathrm{CTAB}$ was added to the lysates, and incubated at $65^{\circ} \mathrm{C}$ for $20 \mathrm{~min}$ and extracted with equal volume of chloroform isoamylalchohol (24:1). Nucleic acid was precipitated from the aqueous phase with 0.6 volume of isopropanol and finally purified using ethanol $70 \%$ [9].

\subsection{Amplification of 16S rRNA}

To amplify the fragment of $16 \mathrm{~S}$ rRNA, the isolated genomic DNA was amplified by using actinospecific forward and reverse primers. The PCR reaction mixture $(50 \mu \mathrm{l})$ contained $50 \mathrm{pmol}$ each of forward and reverse primers, $4 \mathrm{dNTPs}$ at $0.2 \mathrm{mM}$ each, $2.0 \mathrm{mM} \mathrm{MgCl}$, and $0.5 \mathrm{ng} / \mu \mathrm{l}$ bacterial genomic DNA as the template DNA and 1.5U Taq DNA polymerase. The PCR amplification was achieved with $94^{\circ} \mathrm{C}$ for $5 \mathrm{~min}$ as primary denaturing temperature, then $94^{\circ} \mathrm{C}$ for $1 \mathrm{~min}$ as denaturing temperature, $57^{\circ} \mathrm{C}$ for $60 \mathrm{sec}$ as annealing temperature $72^{\circ} \mathrm{C}$ for $105 \mathrm{sec}$ as extension time, in $35 \mathrm{cycles}$, and $72^{\circ} \mathrm{C}$ for $10 \mathrm{~min}$ as final extension time. The PCR product was sent for sequencing. The 16S rRNA partial gene sequence was subjected to BLAST search in the NCBI database. The DNA sequences were aligned and phylogenetic tree was constructed by neighbor joining method using Clustal W [10]. The BLAST search analysis revealed there is a similarity between the strains, PSA-7 and Streptomyces sp. 
Table-1. Phosphate Solubulizing isolates of Actinomycetes

\begin{tabular}{|l|l|l|}
\hline S.No & Name of the isolates & Zone of clearance $(\mathrm{mm}$ in diameter) \\
\hline 1 & PSA-1 & 17 \\
\hline 2 & PSA-2 & -- \\
\hline 3 & PSA-3 & -- \\
\hline 4 & PSA-4 & 24 \\
\hline 5 & PSA-5 & -- \\
\hline 6 & PSA-6 & 12 \\
\hline 7 & PSA-7 & 27 \\
\hline 8 & PSA-8 & -- \\
\hline 9 & PSA-9 & -- \\
\hline 10 & PSA-10 & -- \\
\hline
\end{tabular}

Table-2. Biochemical Characterization of Actinomycetes strains

\begin{tabular}{|c|c|c|c|c|c|c|c|c|c|}
\hline S.No & $\begin{array}{c}\text { name of the } \\
\text { isolate }\end{array}$ & I & MR & VP & citrate & catalase & urease & lipase & $\begin{array}{c}\text { starch } \\
\text { hydrolysis }\end{array}$ \\
\hline 1 & PSA-1 & + & - & - & + & + & - & - & + \\
\hline 2 & PSA-2 & + & - & -1 & $+N \perp$ & + & + & - & + \\
\hline 3 & PSA-3 & + & - & + & + & + & + & + & + \\
\hline 4 & PSA-4 & - & - & - & + & + & - & - & + \\
\hline 5 & PSA-5 & + & + & + & + & + & - & - & + \\
\hline 6 & PSA-6 & + & + & - & + & + & + & + & + \\
\hline 7 & PSA-7 & - & + & - & + & + & - & - & + \\
\hline 8 & PSA-8 & + & - & - & + & + & - & - & + \\
\hline 9 & PSA-9 & + & + & + & + & + & - & - & + \\
\hline 10 & PSA-10 & - & + & - & + & + & - & - & + \\
\hline
\end{tabular}




\section{Results and Discussion}

Actinomycetes are commonly found in all most all habitats. These are prokaryotic, spore forming, filamentous, gram positive bacteria. In the present study totally 10 actinomycetes colonies including white, ash, brown colored colonies with different morphotypes were isolated from forest soils of Mahabubnagar district (Fig.1).

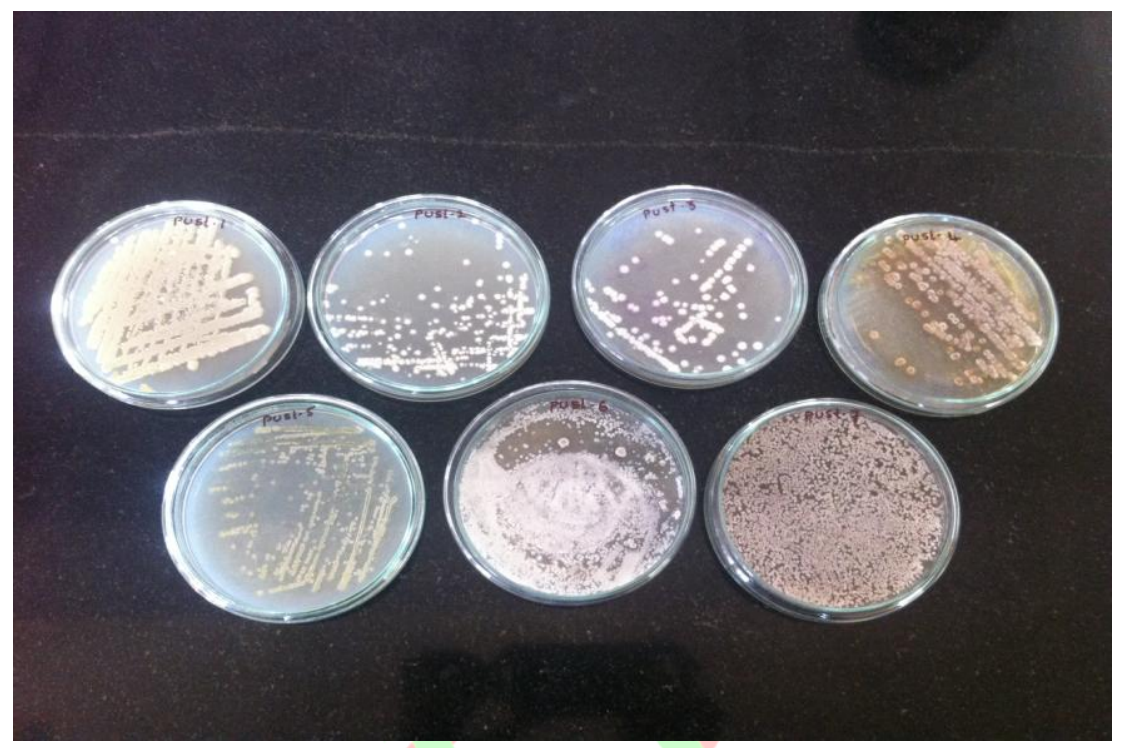

Fig. 1 Pure cultures of Actinomycetes sp.

In the characterization of these isolates several biochemical tests were performed and results were presented in table-2. All isolates were positive for citrate, amylase and catalase tests.

Among the 10 isolates, 4 isolates showed positive phosphate solubilization activity (Table-1). Among them two isolates were very potential. These two strains showed larger zones of clearance indicating an efficient solubilization of phosphate than other strains, on plate assay.

In the process optimization, the optimum $\mathrm{p}^{\mathrm{H}}$ for efficient phosphate solubilization was found to be at 7.0 with an incubation period of 10 days.

The identification of isolate, showing the maximum activity was carried out by using molecular studies as this method was one of the strongest and easiest methods. Amplification of 16S rRNA was obtained with specific forward and reverse primers. Using BLAST search, the NCBI data bank, sequences homologous to the isolate PSA-7 were collected and subsequently aligned using clustalW. A phylogenetic tree constructed based on neighbor joining method using tree view software. The BLAST search analysis revealed that there is a $98 \%$ similarity of the strain with Streptomycetes spp.

\section{Conclusion}

From the above study it is concluded that, actinomycetes are also an efficient strains phosphate solubilization activity. However further studies are needed with respect to inoculum production and their inoculation effect on plant growth should be studied in vivo.

\section{Acknowledgment}

Authors are thankful to Vice-Chancellor Prof. K. Narsimha Reddy and Registrar Prof. K. Venkata Chalam, Palamuru University, Mahabubnagar for their encouragement and lab facilities. 


\section{References}

[1] Donahue, R.L., R.W. Miller and J.C. Shickluna, 1990. Soils: An Introduction to Soils and Plant Growth. Prentice Hall of India private Limited, New Delhi, 110001. pp: 222-4.

[2] Chabot, R. H. Antoun and M.P. Cescas, 1993. Stimulation of growth of maize and lettuce by inorganic phosphorus solubilizing microorganisms. Canadian J. Microbiol., 39: 941-47.

[3] Sundara Rao, W.V.B. and Sinha, M.K., 1963. Phosphate dissolving organisms in the soil and rhizosphere.Ind.J. Agric. Sci., 33: 272-278.

[4] Illmer, P. and F. Schinner, 1992. Solubilization of inorganic phosphate by microorganisms isolated from forest soils. Soil Biol. Biochem., 24:389-95.

[5] Williams, S.T. and Davies, F.L. (1965) Use of antibiotics for selective isolation and enumeration of Actinomycetes in soil. Journal of General Microbiology 38:251-261.

[6] Porter, J.N., Tresner, H.D.(1960). A method for the preferential isolation of actinomycetes from soil. Journal of Applied Microbiology 8:174-178.

[7] Shirling EB, Gottlieb D, Methods for characterization of streptomyces species. Int J Syst Bacteriol 1996; 16:312-40.

[8] Ayyaku, K. and D.Chandramohan. (1971). Occurance and distribution of phosphate solubilizing and phosphatase in marine sediments of Porto-Novo. Mar. bio., 11, 201-205.

[9] Adinarayana Gorajana, Ellaiah Poluri and Axel Zeeck (2010). Cytotoxic compounds from marine actinomycete, African journal of Biotechnology Vol. 9(42), pp. 7197-7202.

[10] Saitou N, Nei M, The neighbor-joining method: a new method for reconstructing phylogenetic trees, Mol Biol Evol, 24, 1987, 189-204 